\title{
SUITABILITY OF A SOUTH AFRICAN SILICA SAND FOR THREE-DIMENSIONAL PRINTING OF FOUNDRY MOULDS AND CORES
}

\author{
K. Nyembwe ${ }^{1}$, D. Oyombo ${ }^{2 *}$, D.J. de Beer ${ }^{3}$ P.J.M. van Tonder ${ }^{4}$
}

\section{ARTICLE INFO}

\section{Article details}

Presented at the 17th annual

international conference of the Rapid

Product Development Association of

South Africa (RAPDASA), held from 2-4

November 2016 in Vanderbijlpark, South Africa

Available online 11 Nov 2016

\section{Contact details}

Corresponding author odady@uj.ac.za

\section{Author affiliations}

1 Department of Metallurgy University of Johannesburg, South Africa

2 Metal Casting Technology Station University of Johannesburg, South Africa

3 Technology Transfer and Innovation Support, North-West University, Potchefstroom Campus, South Africa

4 Advanced Manufacturing Precinct, Technology Transfer and Innovation, Vaal University of Technology
Applications of three-dimensional printing (3DP) to metal casting include, among other things, the direct manufacturing of foundry moulds and cores in refractory materials such as silica sand. The main properties of silica sand that are essentially related to the traditional moulding and core-making processes are: size distribution, clay content, $\mathrm{pH}$, acid demand, and refractoriness. The silica sand used for 3DP must also be appropriately selected for the layer-based manufacturing process involved in 3DP. Properties such as grain size distribution, grain surface morphology, angularity, flowability, and recoating abilities have a particular importance when determining sand suitability. Because of these extra requirements, only a limited range of available foundry silica sands can be used for 3DP processes. The latter situation explains the scarcity and high cost of suitable silica sands, thus contributing to the relatively high operational costs of the 3DP processes for the production of sand moulds and cores. This research paper investigates the suitability of a locally-available silica sand for use in a Voxeljet VX1000 3DP machine. The local silica sand was assessed and compared with an imported silica sand recommended by the manufacturer of 3DP equipment in terms of foundry characteristics and recoating behaviour. The study shows that, despite the differences between the characteristics of the two silica sands, the local sand could be considered a suitable alternative to imported sand for rapid sand casting applications.

\section{OPSOMMING}

Die toepassings van driedimensionele drukwerk op die metaalgietproses sluit onder andere die direkte vervaardiging van gietvorms en kerns van vuurvaste materiale, soos silika sand, in. Die hoofeienskappe van silika sand wat verwant is aan die tradisionele gietvorm- en kernvervaardigingsproses is grootte, verspreiding, klei-inhoud, $\mathrm{pH}$, die suur benodig en vuurvastigheid. Die silika sand wat vir driedimensionele druk gebruik word moet ook met inagneming van die laag-gebaseerde vervaardigingsproses gekies word. Eienskappe soos korrelgrootte verspreiding, greinoppervlakmorfologie, hoekigheid, vloeibaarheid en die vermoë om die oppervlak af te werk is van besondere belang. As gevolg van dié vereistes is daar 'n beperkte reeks van silika sandsoorte wat geskik is. Dit dra by tot die hoë bedryfskoste wat met die driedimensionele druk van sandgietvorms en kerns geassosieer word. Die geskiktheid van 'n plaaslik beskikbare silika sand vir gebruik in ' $\mathrm{n}$ Voxeljet VX1000 driedimensionele drukker is ondersoek. Die silika sand is geassesseer en vergelyk met ingevoerde silika sand wat deur die drukker se vervaardiger aanbeveel word. Die resultate toon dat, ten spyte van die verskille in die sandsoorte se eienskappe, die plaaslike sand as 'n aanvaarbare plaasvervanger oorweeg kan word. 
Applications of additive manufacturing (AM) processes to sand casting, referred to as 'rapid sand casting', essentially include the production of sand patterns and the direct fabrication of sand moulds and cores [1]. The latter application has become very prominent in the last decade, with the introduction to the market of large and high-speed three-dimensional printing (3DP) equipment capable of being used for industrial casting production [2]. Examples of this 3DP technology include the S-Max from ExOne [3] and the VX series equipment from Voxeljet [4].

AM processes used to fabricate sand moulds and cores are based on well-established resin bonded sand casting methods such as the shell and furan processes, which are implemented in the laser sintering (LS) and three-dimensional printing rapid prototyping technologies respectively $[5,6]$. The shell process is a heat-cured resin bonded sand system, while the furan process is a no-bake resin bonded sand technology $[7,8]$. The refractory sand used in most of the current AM processes is silica sand.

Silica sand is one of the more widely-used refractory sands in conventional metal casting applications [9], due its extensive availability worldwide, and its cost-effectiveness compared with other specialised foundry sands such as chromite, olivine, and zircon sands. Some of the most important foundry properties of silica sand include grain size distribution, grain shape, chemical purity, refractoriness, and thermal expansion. The characteristics of silica sand ensure that resin consumption is minimised, the mould strength is optimised, and the resulting castings are sound and defect-free.

The layer-by-layer manufacturing technique used in LS and 3DP processes imposes additional material requirements. The AM processes fundamentally differ from conventional sand moulding and core-making processes due to the absence of the sand wet-mixing and compaction steps. For example, during the $A M$ fabrication of sand moulds and cores, sand segregation needs to be minimised and the production of high density parts promoted through the inherent properties of silica sand, in terms of the particular size distribution and its low angular and highly spherical grain shape.

A large variety of silica sands that are suitable for foundry applications are available in South Africa. These sands were recently tested at the University of Johannesburg as part of a survey commissioned by the National Foundry Technology Network (NFTN) agency [10]. Unfortunately, none of these silica sands are being used for AM processes that are locally available (as LS at the Central University of Technology (Technology 2016) and 3DP at the Vaal University of Technology [12]). The running cost of these processes is increased by the high cost of importing silica sands from overseas.

This study attempts to address this problem by investigating the suitability of one variety of South African silica sand for use in the AM fabrication of sand moulds and cores. The study also compares the performance of this South African silica sand with an overseas silica sand recommended by the supplier of one of the 3DP technologies in use locally. The local silica sand was selected for its superior properties, as revealed by the NFTN survey mentioned above.

\section{EXPERIMENTAL PROCEDURES}

The study makes used of two silica sands. The first, referred to as 'imported sand', was sourced from overseas and recommended by Voxeljet, who manufacture the VX 1000 3DP system. The second sand, referred to as 'local sand', was obtained in South Africa. It was selected for its good reputation in the traditional sand casting industry [10]. The experimental work was carried out in three stages: characterisation of refractory sands, determination of foundry properties, and three-dimensional printing recoating trials. In this investigation, the Voxeljet VX 1000 - available at the Advanced Manufacturing Precinct (AMP) of the Vaal University of Technology Southern Gauteng Science and Technology Park - was used for the additive manufacturing of sand parts. Recoating tests were conducted at Voxeljet $\mathrm{GmbH}$ in Friedberg, Germany.

\subsection{Characterisation of refractory sands}

The two types of refractory sands considered were tested to determine the following attributes:

- Grain size distribution 
- $\quad$ Fineness (AFS number and AGS)

- Loss on ignition

- $\mathrm{pH}$

- $\quad$ Acid demand

- $\quad$ Sintering point

- Clay content

- $\quad$ Bulk density

- Specific gravity

- $\quad$ Silica content

- Grain shape

Procedures recommended by the American Foundrymen Society (AFS) [13] were followed to determine all the properties listed above for both sands, except for the silica content and grain shape analysis. The latter sand properties were determined by x-ray diffraction (XRD) and scanning electron microscopy (SEM) techniques respectively.

The imported and local silica sands for use on the three-dimensional printer equipment were supplied as material pre-coated with sulphonic acid catalyst. These sands were analysed in two different conditions: as-received, and washed. The washing process was conducted according to the AFS procedures [13] in a boiling solution of sodium tetra-phosphate followed by water rinsing. This sand treatment was intended to remove the sulphonic acid coating of the sands. Washed sand was subsequently oven-dried at 100 degrees Celsius for two hours.

\subsection{Determination of foundry properties}

Sand specimens for tensile, bend, and compression strength tests were produced by additive manufacturing on the Voxeljet VX 1000 using the two different types of sand. The drawings and dimensions of the test specimens conform to the AFS specifications [13].

These test specimens were then used to determine the following foundry properties:

- $\quad$ Tensile and bend strength

- $\quad$ Friability

- Hardness

- $\quad$ Surface finish

Appropriate foundry sand testing equipment and corresponding testing instructions from Ridsdale and Ridsdale Dietert [14] were used to determine strength, hardness, and friability. The surface finish was assessed using a TIME instrument model TR 110 [15].

Sand specimens were tested in both uncured and cured conditions. The uncured condition corresponds with the AM-fabricated state after twenty-four hours' self-setting of the sample at room temperature. The cured state relates to the post-processing of the sand specimen by heating in an oven at 110 degrees Celsius for two hours.

\subsection{Three-dimensional printing recoating trial}

The local sand was assessed for recoating behaviour using a Voxeljet VX1000. The trial consisted of printing a flat sand part and visually examining the surface for visible recoating defects such as ditches, drag marks, and blockages in the recoated sand surface.

\section{$3 \quad$ RESULTS AND DISCUSSION}

\subsection{Properties of refractory sands}

Table 1 shows the properties of the imported and local silica sands in the as-received and washed states. Noticeable and appreciable differences between the two silica sands can be observed regarding their fineness, silica content, loss on ignition (LOI), clay content, and specific gravity.

- The sand fineness is represented by AFS number and average grain size. The local silica sand with an AFS number of 51 is coarser after washing than the imported sand (AFS number of 66). This trend can also be observed when considering the average grain size values. The difference 
in sand fineness implies that smoother castings could be expected from the imported sand than from the local sand. However, the permeability of local sand moulds will likely, in general, be higher than the ones made out of the imported sand moulds. Thus casting will probably be less prone to gas defects when using the local sand.

- The local sand with a silica content of 98 per cent after washing appears to be cleaner than the imported sand (silica content of 97 per cent). This makes the local sand slightly more refractory than the imported sand. This is also evident from the sintering test results of the as-received sands. The sintering point of the as-received local sand was found to be 1,600 degree Celsius - higher than the sintering point of the imported sand (1,500 degree Celsius). The local sand could be best suited for casting alloys with a high melting and pouring temperature, such as steel alloys.

- The loss on ignition value for the local sand in the as-received and washed states is 0.20 per cent, which is much lower than the values of the imported sand in the as-received and washed state ( 0.53 per cent and 0.40 per cent respectively). This observation appears to be in line with the difference in clay content between the two sands. The local sand has a lower clay content at 0.48 per cent than the imported sand at 0.56 per cent. The differences in LOI and clay content between the local and imported sand could possibly corroborate the previous observation about the silica content of the two sands, and reinforce the fact that the local sand is cleaner than the imported sand.

- The specific gravity is constant for both sands at around $2.63 \mathrm{~g} / \mathrm{cc}$. However, the bulk density values of the two sands seem to indicate that the local sand, with a bulk density of $1.75 \mathrm{~g} / \mathrm{cm}^{3}$ after washing, is heavier than the imported sand, with a bulk density of $1.58 \mathrm{~g} / \mathrm{cm}^{3}$. This difference could indicate a better packing of the local silica sand compared with the imported silica sand.

Table 1: Table of properties

\begin{tabular}{|l|c|c|c|c|}
\hline \multirow{2}{*}{ Sand parameter } & \multicolumn{2}{|c|}{ Imported sand } & \multicolumn{2}{c|}{ Local sand } \\
\cline { 2 - 5 } & As received & Washed & As received & Washed \\
\hline Acid demand value $[\mathrm{ml}]$ & 0.00 & 0.55 & 0.00 & 1.02 \\
\hline AFS grain fineness & 65.45 & 66.61 & 48.29 & 51.53 \\
\hline Average grain size $[\mu \mathrm{m}]$ & 211.63 & 223.54 & 326.52 & 328.65 \\
\hline Bulk density $\left[\mathrm{g} / \mathrm{cm}^{3}\right]$ & 1.5291 & 1.5820 & 1.6468 & 1.7516 \\
\hline Loss on ignition $[\%]$ & 0.53 & 0.40 & 0.20 & 0.20 \\
\hline $\mathrm{pH}$ & 4.68 & 7.58 & 4.18 & 8.05 \\
\hline $\mathrm{SiO} 2[\%]$ & 97.08 & 96.99 & 97.83 & 98.12 \\
\hline Sinter point $\left[{ }^{\circ} \mathrm{C}\right]$ & 1500 & 1600 & 1600 & 1600 \\
\hline Specific gravity $[\mathrm{g} / \mathrm{cc}]$ & 2.63 & 2.62 & 2.64 & 2.62 \\
\hline Total clay content $[\%]$ & 0.56 & - & 0.48 & - \\
\hline
\end{tabular}

Figures $1 \mathrm{a}$ and $1 \mathrm{~b}$ show the size distribution of the imported and local silica sands in the as-received state and after washing. There is a major difference between the two sands with regard to the size fraction of the bulk of the material. More than 80 per cent of the imported sand material falls between $75 \mu \mathrm{m}$ and $212 \mu \mathrm{m}$, while the same quantity of local sand material falls between $106 \mu \mathrm{m}$ and $425 \mu \mathrm{m}$. This difference in size distribution explains the difference in AFS number and average grain sizes observed in Table 1. This will likely affect the surface finish and dimensional accuracy of the sand part produced on the Voxeljet printer, which was set to operate with a layer thickness of $150 \mu \mathrm{m}$.

The size distribution of the local sand also appears to be more widely spread than that of the imported sand, whose size distribution is visibly narrower. Due to this difference, the local sand could be more prone than the imported sand to sand segregation during additive manufacturing.

Figure 2 shows the grain shape of the imported and local silica sands as revealed by the scanning electron microscope. It can be seen that the grain shape of the local sand is sub-rounder and more spherical than the grain shape of the imported sand, which is more angular and elongated. This difference in grain shape is consistent with the result of the bulk densities in Table 1. In general, round and spherical grain shape sand packs better than angular and elongated grain shape sands, and will generally produce much denser and more rigid moulds than the latter. 


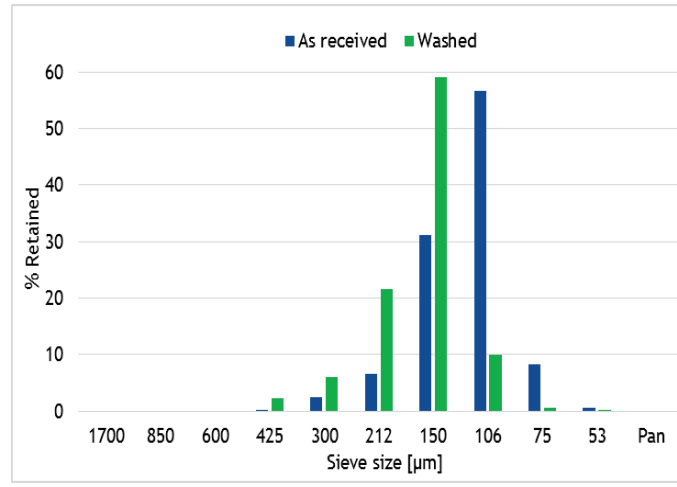

(a): Imported sand

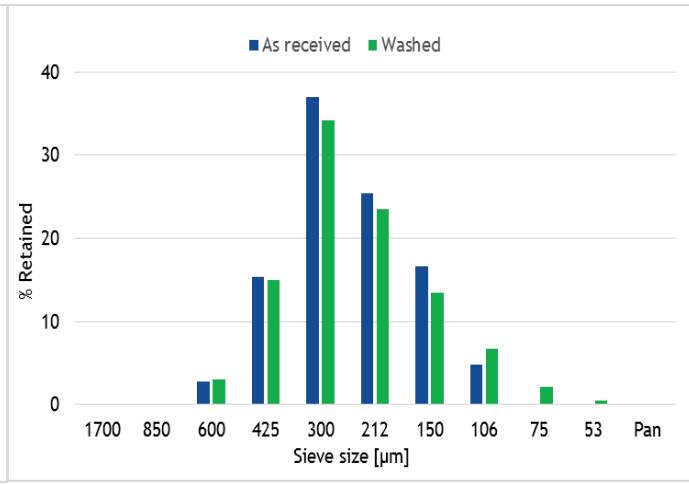

(b): Local sand

Figure 1: Grain size distribution of silica sands

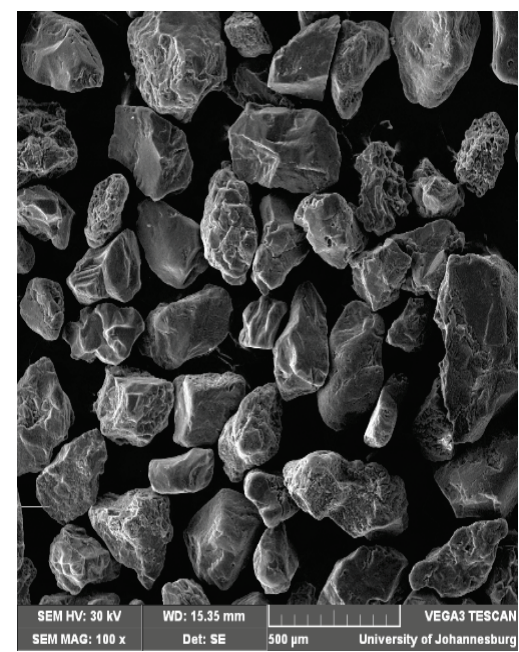

(b) Washed imported sand

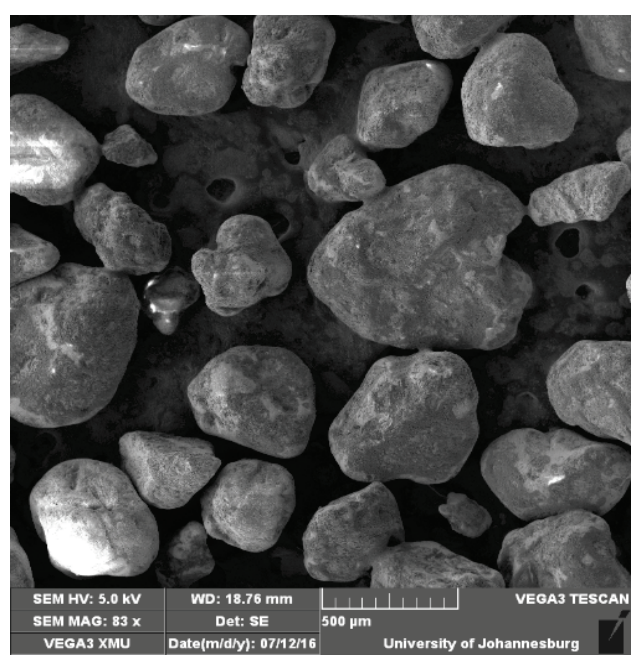

(a) Washed local sand

Figure 2: Grain shape of silica sands from a scanning electron microscope

\subsection{Foundry properties of sand specimens}

Figure 3 shows the tensile and bend test results of sand specimens for the imported and local sands in both the uncured and the cured conditions. It is evident from Figure 3 that curing and/or heating samples in the oven increases the strength of the specimens. The local and imported sands produce similar tensile and bend strengths of $150 \mathrm{~N} / \mathrm{cm}^{2}$ and $275 \mathrm{~N} / \mathrm{cm}^{2}$ respectively, after heating of the test specimens.

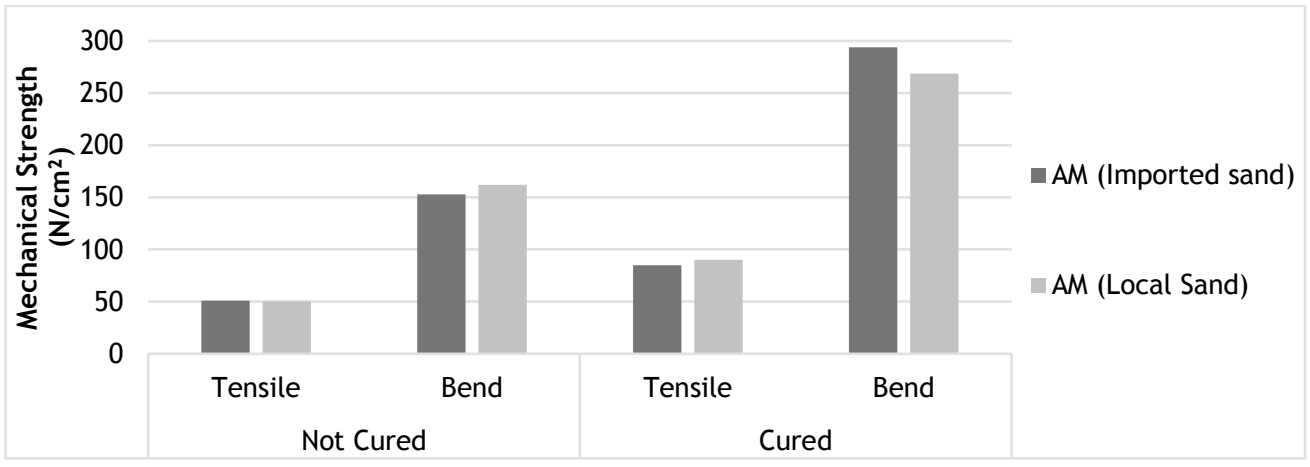

Figure 3: Tensile and bend strengths of sand specimens 
The slight differences between the strength values of the imported and local sands observed in Figure 3 were considered to be non-significant, as they fall within the error margin of the testing methods used. It does not appear that the differences of sand properties found in the previous sections had any effect on their strength properties.

Figure 4 shows the hardness test results of sand specimens for both the imported and the local sands in uncured and cured conditions. The hardness does not appear to be affected by heating the sand samples, as it remains constant between 91 and 94 green hardness scale. No significant difference in sample hardness was found between the two silica sands. Once again, the differences in sand characteristics did not produce differences in the hardness of the sand parts between the two silica sands.

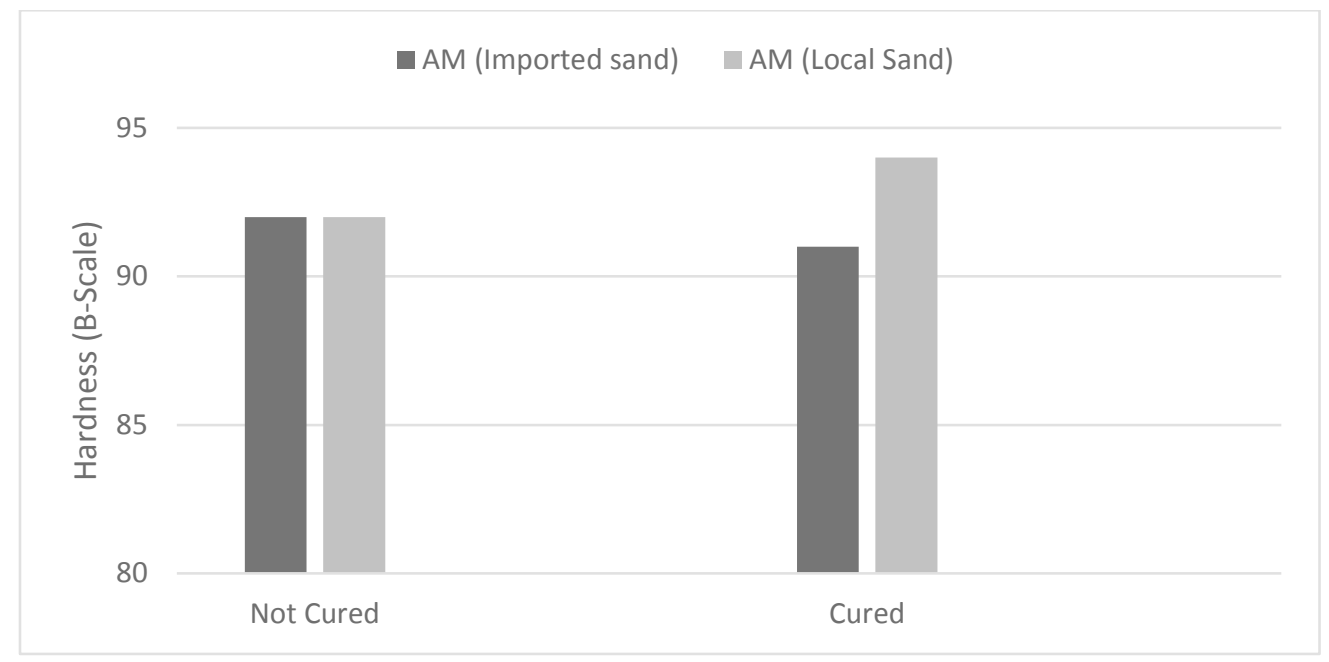

Figure 4: Hardness test results of sand specimens

Figure 5 shows the friability test results of sand specimens for both the imported and the local sands in uncured and cured conditions. The results show that, after heating, the friability decreases by 53 per cent for both sands. No appreciable difference in the friability was found between the two silica sands after sand heating. The friability of the local sand was found to be 17 per cent, and that for local sand 15 per cent. The differences in sand characteristics between the imported and the local sands did not influence the friability, which is primarily a function of the resin content of the sand.

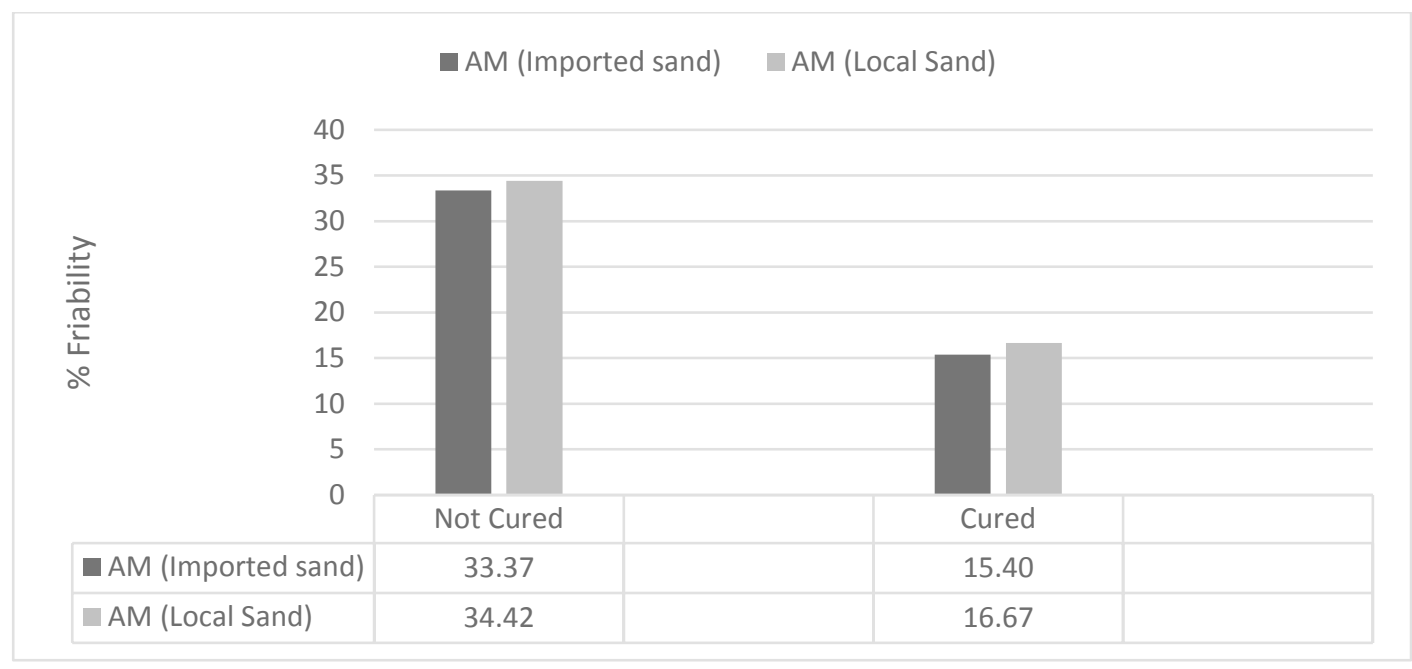

Figure 5: Friability test results of sand specimens

Figure 6 shows the surface finish test results of sand specimens for both the imported and the local sands in uncured and cured conditions. The heating of the sand specimens did not influence the 
surface finish of the sand samples. The local sand produces sand specimens with a rougher surface than the smoother surface sand specimens of the imported sand. This observation corresponds with the difference in sand fineness between the two sands found in Table 1.

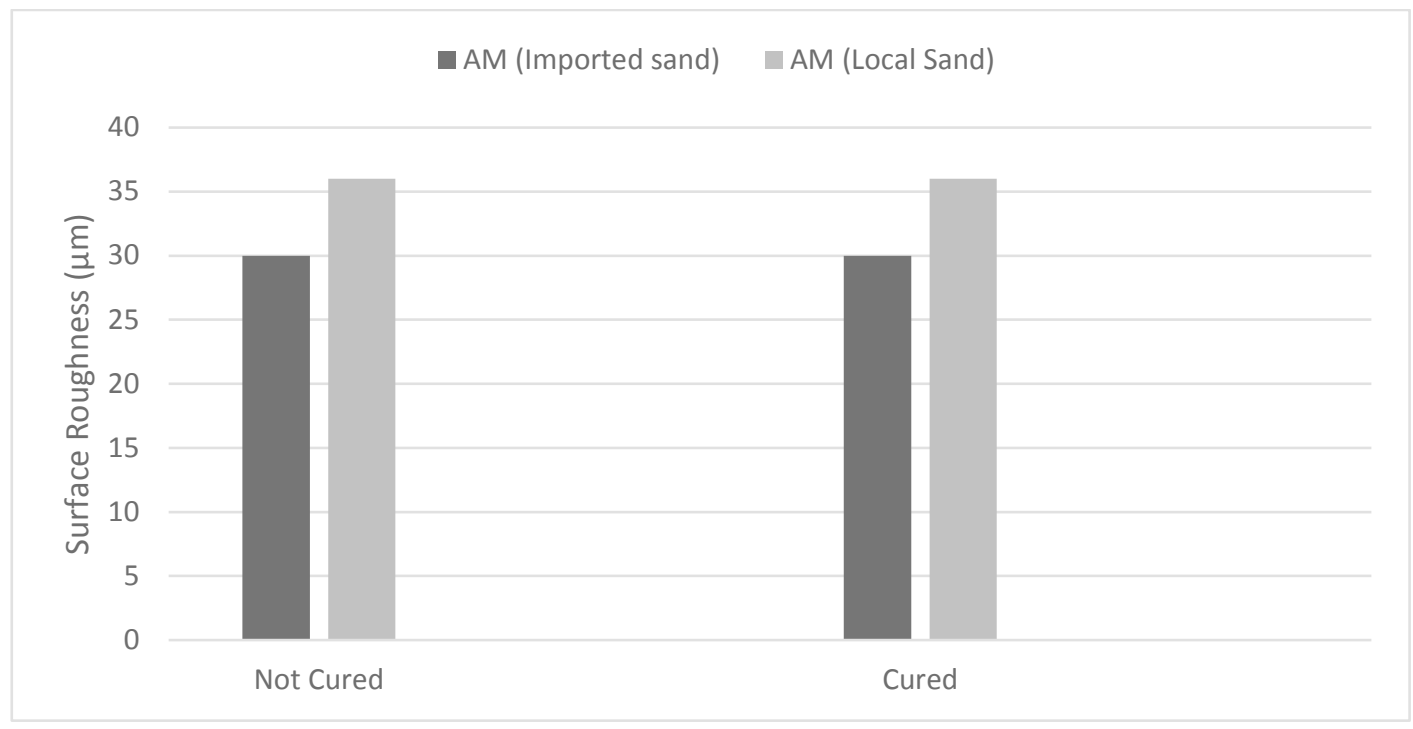

Figure 6: Roughness test results of sand specimens

\subsection{Recoating behaviour of local silica sand}

Figure 7 is a photograph of an $A M$ trial using the imported sand at Voxeljet $\mathrm{GmbH}$ in Friedberg, Germany. The results of the trial as reported by Voxeljet indicated that, although the local sand was rough, the powder bed after recoating appeared smoother and homogeneous [16]. It was therefore assumed that the printed parts would not exhibit any defects due to recoating during the AM process.

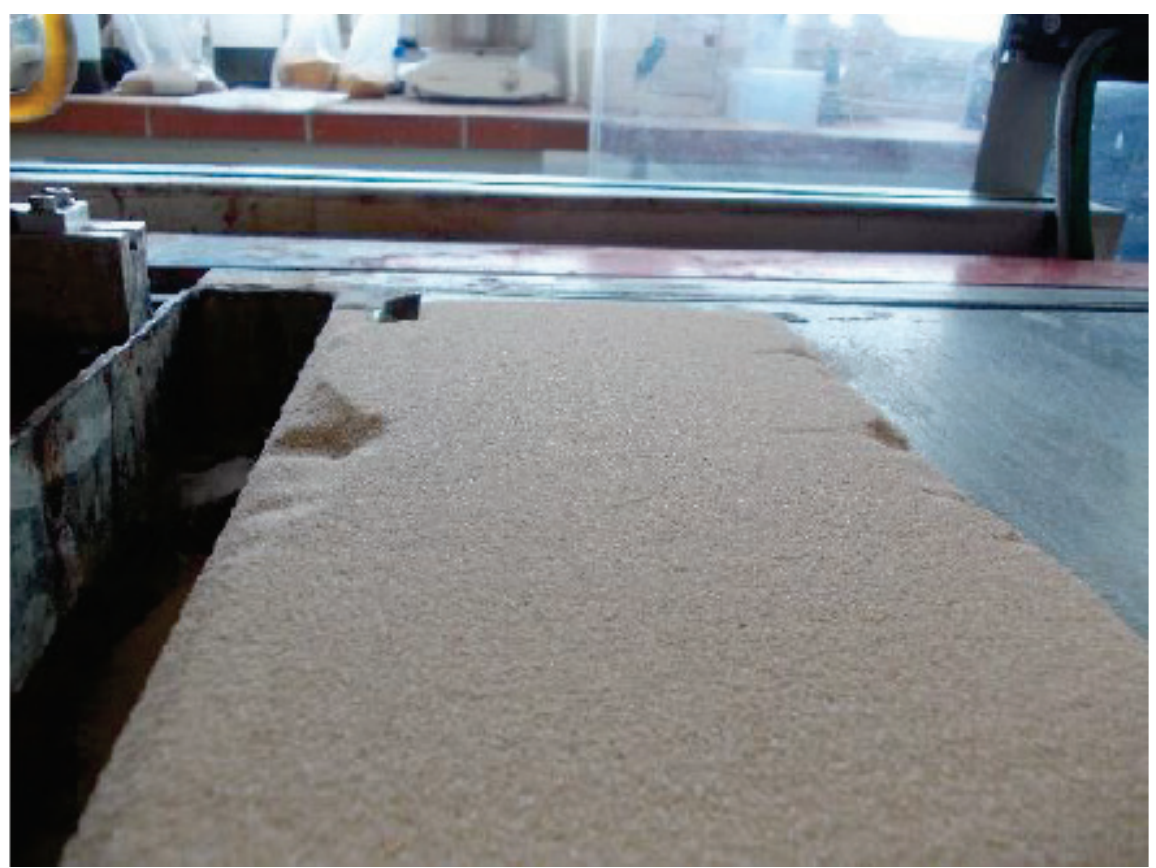

Figure 7: Surface quality produced from AM trial on a Voxeljet VX1000 using the local sand 
This investigation has proved that a local silica sand could be considered for the AM of sand moulds and cores using a Voxeljet VX 1000 3DP, in place of the imported silica sand currently recommended by the 3DP equipment manufacturer. In doing so, an appreciable operational cost saving could be achieved by using the local silica sand at R1/ kg, as opposed to the imported sand priced at R26/kg. The foundry properties of AM parts produced from the local silica sand and its recoating behaviour during printing were satisfactory, and comparable to those of the imported silica sand. The next step in this investigation will be to assess the quality of castings obtained from AM-produced moulds and cores using the local silica sand.

\section{REFERENCES}

[1] Chhabra, M. and Singh, R. 2011. Rapid casting solutions: A review, Rapid Prototyping Journal, pp. 328350.

[2] Gardan, J. 2016. Additive manufacturing technologies: State of the art and trends, International Journal of Production Research, 54(10), pp. 3118-3132.

[3] ExOne. 2016. S-MaxTM Industrial Production 3D Printer: The established 3D printer for large cores and molds [Online]. Available: http://www.exone.com/Systems/Production-Printers/S-Max [Accessed 25 July 2016].

[4] VoxelJet. 2015. VX1000: The universal, best printer from Voxeljet: Ideal for all plastic and sand processes [Online]. Available: http://www.voxeljet.de/en/systems/3d-druckervx10000/ [Accessed 25 July 2016].

[5] Nyembwe, K., De Beer, D., Van der Walt, J. and Bhero, S. 2011. A case study of additive manufacturing process selection for a casting application using the analytic hierarchy process, in Proceedings of the 115th MetalCasting Congress, Schaumberg, Chicago.

[6] Beeley, P. 2001. Foundry technology. Oxford: Butterworth-Heinemann.

[7] Chua, C.K., Leong, K.F. and Lim, C.S. 2010. Rapid prototyping: Principles and applications, Singapore: Worldscientific.

[8] Snelling, D., Williams, C. and Druschitz, A. 2014. A comparison of binder burnout and mechanical characteristics of printed and chemically bonded sand molds [Online]. Available: http://sffsymposium.engr.utexas.edu/sites/default/files/2014-018-Snelling.pdf [Accessed 21 July 2016].

[9] Brown, J.R. 2004. Ferrous foundryman's handbook. Burlington: Butterworth-Heinemann.

[10] National Foundry Technology Network. 2012. Sand management. Pretoria: National Foundry Technology Network

[11] Central University of Technology. 2016. Centre for Rapid Prototyping and Manufacturing (CRPM) [Online]. Available: http://www.cut.ac.za/crpm/ [Accessed 23 July 2016].

[12] Vaal University of Technology. 2013. Technology Transfer and Innovation (TTI) [Online]. Available: http://www.vut.ac.za/index.php/corporate-services/units/tti/tti [Accessed 24 July 2016].

[13] American Foundry Society. 2006. Mold \& core test handbook. United States of America: American Foundry Society.

[14] Ridsdale and Ridsdale Dietert. 2009. Foundry sand testing equipment operating instructions [Online]. Available: http://www.basrid.co.uk/ridsdale/images/pdf/AFS_OIM.pdf [Accessed 20 July 2016].

[15] T.H. Technology. 2007. Surface roughness tester [Online]. Available: http://www.timeinstrument.com/TR100.html [Accessed 20 July 2016].

[16] Mogele, F. 2016. Report on sand qualification of foundry sands for 3D-printing on VX-machines from Vaal University (South Africa). Bayern: VoxelJet. 